\title{
Opportunities in the teaching of medical specialties, regarding influenza and COVID-19
}

Jesús Reyna-Figueroa, ${ }^{1 *}$ Arely A. Bejarano-Juvera, ${ }^{2}$ César A. Arce-Salinas, ${ }^{3}$ Hilario Martínez-Arredondo ${ }^{4}$ and Rodolfo Lehmann-Mendoza ${ }^{5}$

${ }^{1}$ Department of Teaching and Research; ${ }^{2}$ Department of Pediatrics; ${ }^{3}$ Directorate; ${ }^{4}$ Medical Prevention Management; ${ }^{5}$ Sub-directorate of Health Services. Petróleos Mexicanos, Hospital Central Sur de Alta Especialidad, Mexico City, Mexico

\begin{abstract}
Medical specialties' teaching is an area of health systems that deserves special consideration in light of the lessons learned from influenza and COVID-19; educational programs and implementation of the training strategies that are used must be reevaluated, since the level of training of most specialty students does not allow to consider them as personnel who can face these global problems. The number of specialization courses has exponentially grown, and their main threat is the cancellation or partial execution of their academic programs as a consequence of not implementing functional operational strategies during a contingency.
\end{abstract}

KEY WORDS: COVID-19. Influenza. Pandemic. Medical education. Medical specialties.

\section{Oportunidades perdidas en la enseñanza de especialidades médicas, a propósito de la influenza y COVID-19}

\section{Resumen}

La enseñanza en las especialidades médicas es un rubro de los sistemas de salud que merece consideraciones especiales de acuerdo con las lecciones aprendidas de la influenza y COVID-19. Deben reevaluarse los programas educativos y las estrategias de capacitación implementadas, ya que la preparación escolar de la mayoría de los alumnos no les permite ser considerados como personal que pueda enfrentar esos problemas globales. Los cursos de especialización han crecido en número, pero su principal amenaza es la suspensión de los programas académicos o que sean parcialmente cubiertos como consecuencia de no implementar estrategias operativas funcionales durante una contingencia.

PALABRAS CLAVE: COVID-19. Influenza. Pandemia. Educación médica. Especialidades médicas.

\section{Introduction}

Infectious pandemics occur when a new virulent microbial strain emerges against which the human population has no immunity and causes significant numbers of sick people and deaths. In the $20^{\text {th }}$ century, the influenza virus caused three of them: the Spanish flu (1918), the Asian flu (1957) and the Hong Kong flu (1968), ${ }^{1}$ and one more in 2009 caused by the type A H1N1 subtype. ${ }^{2}$ The Centers for Disease Control and Prevention reported at least 52 million accumulated deaths among all four, ${ }^{3,4}$ which corresponds 


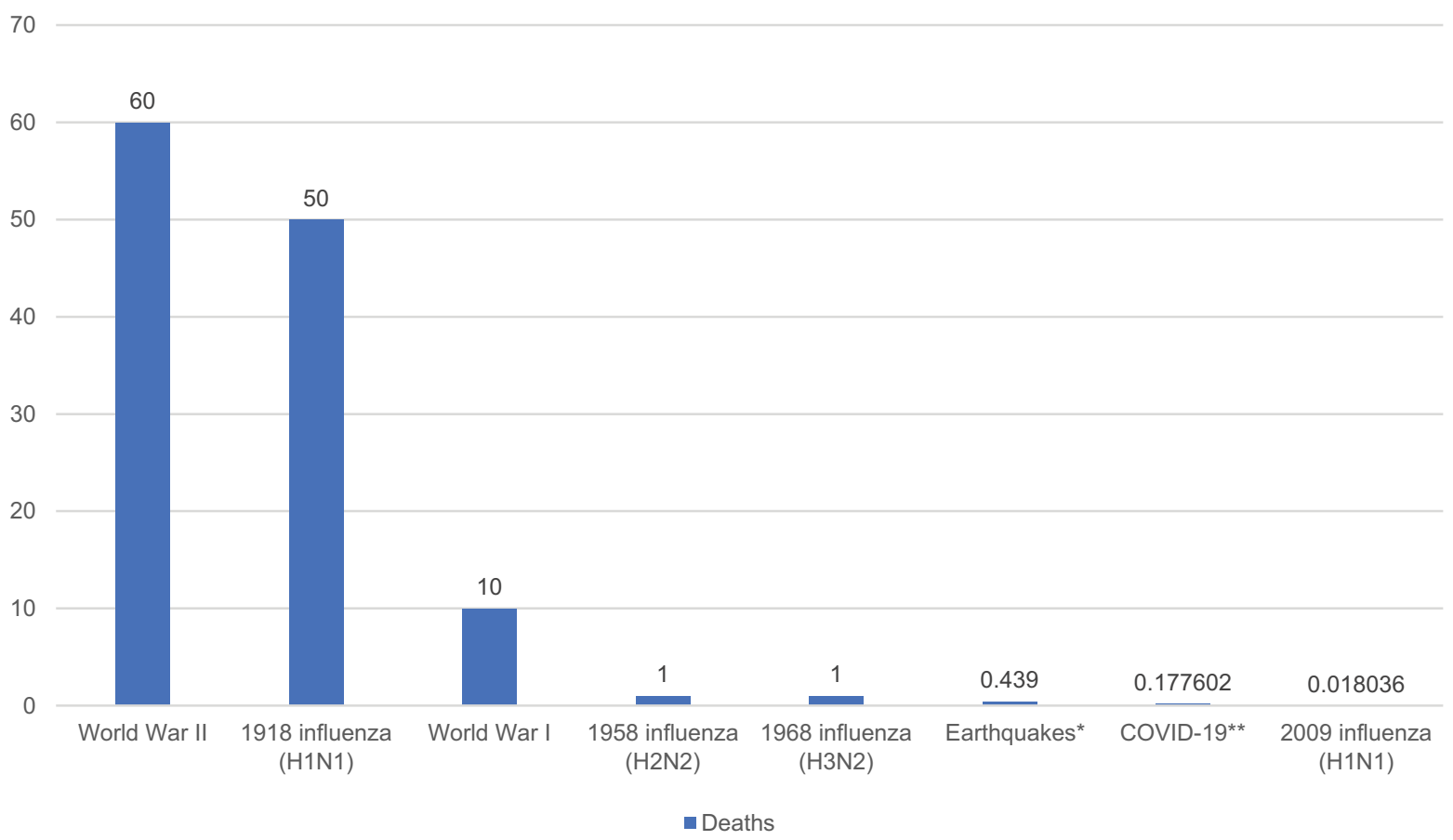

Figure 1. Number of historically reported deaths in pandemics and disasters. Scale $=n \times 1$ million. *Sum of deaths of the five earthquakes considered the most deadly: Haiti in 2010, Peru in 1970, Chile in 1939, Guatemala in 1976 and Nicaragua in 1972. ${ }^{* *}$ Number of deaths from COVID-19 until April 21, 2020.

to approximately 18 million less deaths than those caused by both world wars, ${ }^{5,6} 118$ times more than the 439 thousand deaths resulting from the five earthquakes with the highest number of deaths in modern history. COVID-19 accumulates 9.8 times more deaths than those caused by H1N1 influenza in 2009 (Fig. 1).

Health crises are situations that provide the opportunity to reorder health systems, since to confront them, those actions that show limitations during the contingency are modified. ${ }^{7}$ General consensus establishes that pandemics are inevitable, and it could therefore be assumed that the world is prepared to deal with these events that are of high-impact on the population; 8,9 however, analysts have reiterated that there is insufficient preparedness for an adequate response, and they predict the collapse of hospital systems and the loss of many lives for that reason. ${ }^{10}$

According to the experts, after overcoming the COVID-19 crisis, problems in the economy, education and health will be the consequences for inadequately prepared countries..$^{11-13}$ Unfortunately, in medicine, the opportunities epidemiological demographic and economical changes generate to make adjustments to their programs are missed, with losses of similar magnitude to ignoring the occasions to vaccinate

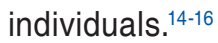

Medical education is an area of health systems that would deserve special considerations during the time in which post- and pre-pandemic periods coincide (an interval that begins when a crisis is overcome and a new alert is opened waiting for another contingency), ${ }^{17}$ during which the learned lessons can be analyzed. In this period, improving teaching in medical courses should be imperative, based on an analysis of the actions that have been carried out, evaluating the successes, placing special emphasis on errors and pointing out improvements. The results and conclusions will be the bases for the pre-pandemic training of human resources, improvement of study plans, assurance of supplies and development of inter-institutional agreements, always considering that this period is of uncertain duration since it is difficult to predict when the next health crisis will occur. In both periods, which actually are inseparable and indivisible, the common factor will always be epidemiological surveillance and technological improvement (Fig. 2).

\section{Opportunities in medical specialty teaching}

Teaching in health, currently considered anachronistic, is in the midst of a transformation, in which the requirements for being admitted to a specialization 


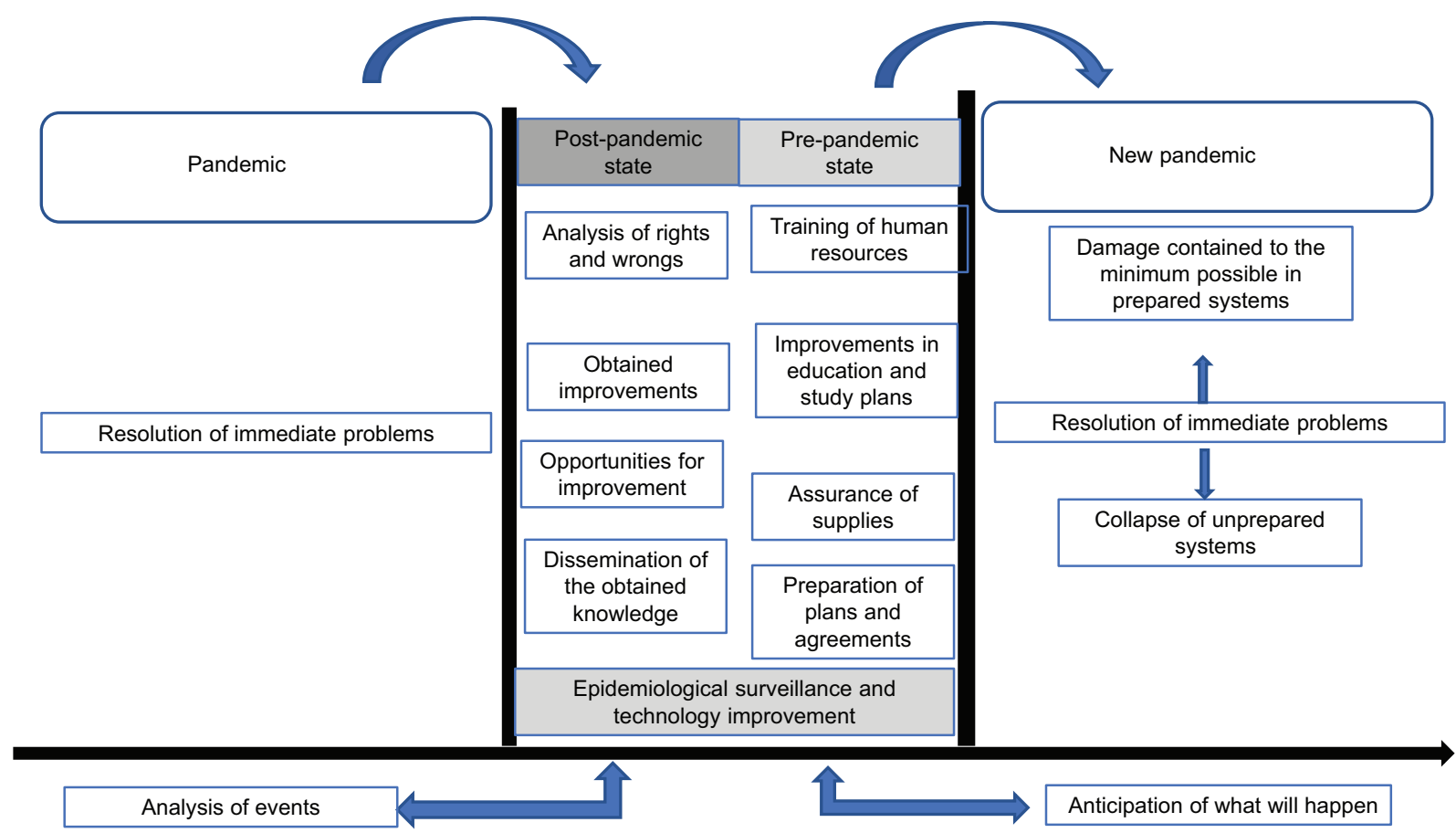

Figure 2. Health systems play a leading role in pandemics and establish actions for solving immediate problems. Once the pandemic has been overcome, actions are prepared to contain the next one. In the period in which both moments, post- and pre-pandemic, converge, there is an opportunity for restructuring education in medical specialties, seeking strategies so that in the future it is not interrupted and for improving health personnel knowledge.

course, the quality of programs, the training strategies used and the way human resources can be included in the system that trained them must be reassessed, in order for the investment made to return benefits to the organization. ${ }^{17}$

Thus, health crises have at least two areas of opportunity for medical specialization. The first one can modify the form of teaching in medical specializations, so that in future events containment and mitigation measures do not impact on the development of operational programs and prevent their interruption. Generally, measures to contain the transmission of microorganisms that are transmitted from person to person, such as those of respiratory nature, are based on distancing and social isolation, whereby slowing the rate of spread of the disease is sought; ${ }^{6,18}$ in a poorly prepared system, these measures contribute to implement incomplete courses, with the risk of inadequate training of future specialist physicians.

The other area regarding medical education is related to the capability of pandemics to reveal systems' poor responses, where scientists with limited knowledge and difficulties in decision-making stand out.19,20

Health systems should be better prepared in matters of teaching, have workers trained in handling general action protocols; otherwise, in conjunction with medical schools, they should acquire greater responsibility in the training of the physicians who will confront contingencies in the future. ${ }^{21}$ Every health professional should possess the basic knowledge that helps to reduce chaos, resistance and panic, but, above all, be a true support in the execution of decisions, protected by the global approach of a system that operates regardless of the nature of the pathogen or its origin. ${ }^{10}$

\section{Factors associated with the fulfillment of academic programs during a pandemic}

The number of specialization courses in medical residencies has grown exponentially. Contradictorily, investment and budget increase to support their success do not appear to be a priority for health systems, ${ }^{22}$ even though it is evident that the countries that have invested more in medical education and that have a structured selection system have improved their organizations until becoming the most important on the planet. ${ }^{23}$

In addition to the urgency and priorities that have to be addressed during a pandemic, ${ }^{24}$ hospital medical specialization courses have as main threat the discontinuation of their academic programs as a 


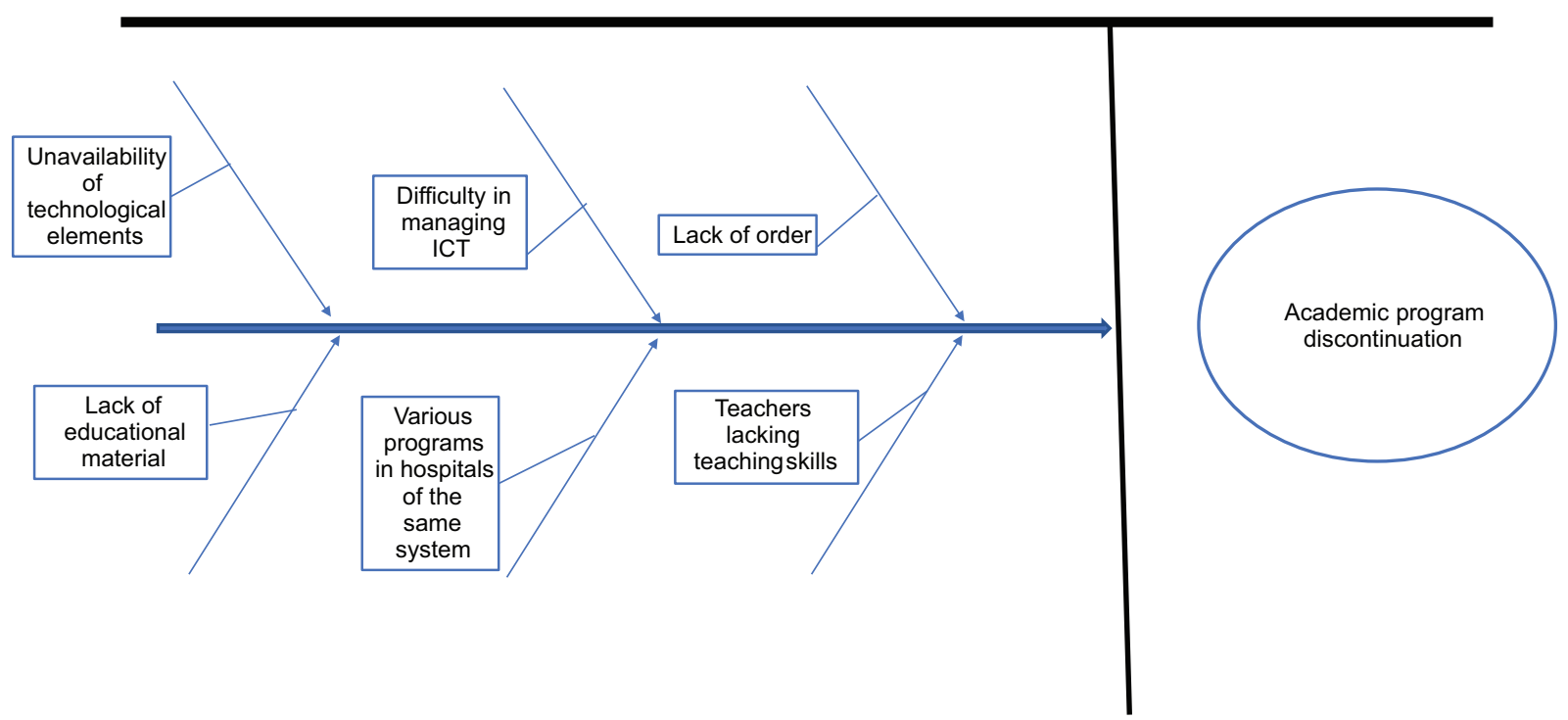

Figure 3. Factors associated with discontinuation of academic programs in medical specialty courses during a pandemic. ICT = information and communication technologies.

consequence of their functional insufficiency and lack of educational strategies to provide them with solvency. ${ }^{25}$ Administrative disorder, improvisation, ignorance or unavailability of information and communication technologies (ICTs), lack of information banks with educational material or non-acquisition of teaching skills by teachers are the main causes that favor that an academic program does not continue in a contingency (Fig. 3). Achieving new teaching models based on educational design, use of emerging technology and focusing on future medical care needs are the main challenges of any institution immersed in education that claims to be successful. ${ }^{26}$

The use of ICT for online or distant learning may solve the impossibility of conducting sessions with the traditional group technique during respiratory disease outbreaks. ${ }^{27}$ Few studies have reported the experience of using ICT in medical residencies, even though general idea is that they are widely used; however, greater integration of study plans is required. ${ }^{28} \mathrm{Re}$ al-time or deferred online transmissions are highly useful tools not only in health crises; their use as a complement or as a primary form of contact is increasingly common in professions where time is limited and some content to be reviewed at pre-established times is chosen. The economic aspect represents also an argument in favor: online learning is considered low-cost, and thus it could be taken more advantage of in medicine. ${ }^{29}$
Based on these concepts, collaborative-cooperative strategies constitute an improvement option, some based on "the inverted classroom", where each student reviews the thematic contents at his/her own pace and preserves virtual group meetings to carry out exercises or simulations that reinforce things learned. This strategy includes conducting trials and video analyses, as well as virtual troubleshooting.

Group sessions should encourage the formation of teams to solve problem exercises, analyze texts, use double-output diaries and compete in games, in such a way as to avoid the traditional modality of teachers before passive students, who should assume responsibility for activities; teamwork forces them to participate in sessions. This should be the routine way to work the theoretical part of courses, whether or not there is an epidemiological emergency. As a complement, medical schools should implement programs to increase the teaching experience and communication skills of their professors, in addition to demanding for them to improve their teaching process ${ }^{30}$ (Fig. 4).

\section{Teaching on the management of pandemics and disasters}

The document on preparedness and response in the face of a pandemic, developed by the World Health Organization, establishes that planning and advance preparations are essential to attenuate the impact of influenza pandemics. ${ }^{26,31}$ 


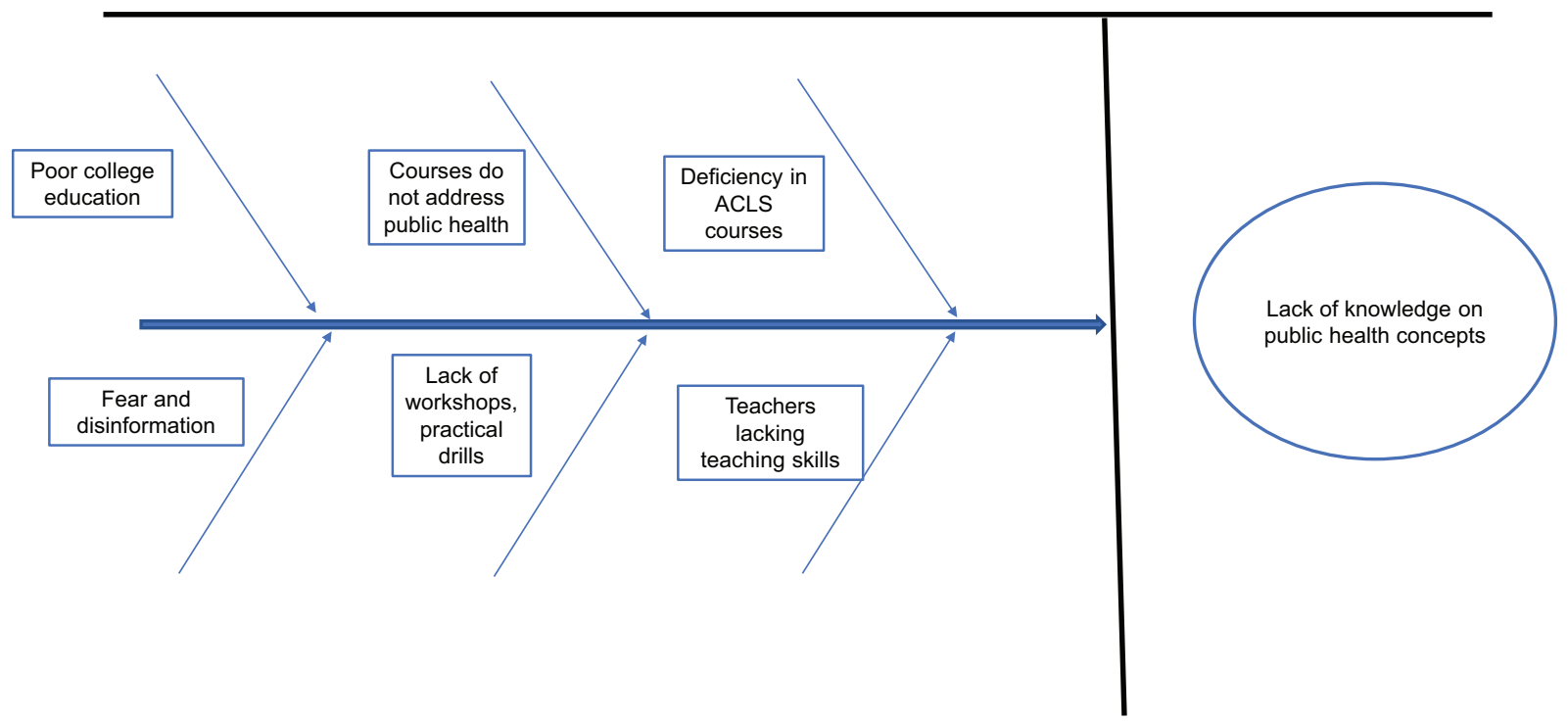

Figure 4. Causes of lack of knowledge on public health matters during a pandemic in health professionals. ACLS = Advanced Cardiovascular Life Support.

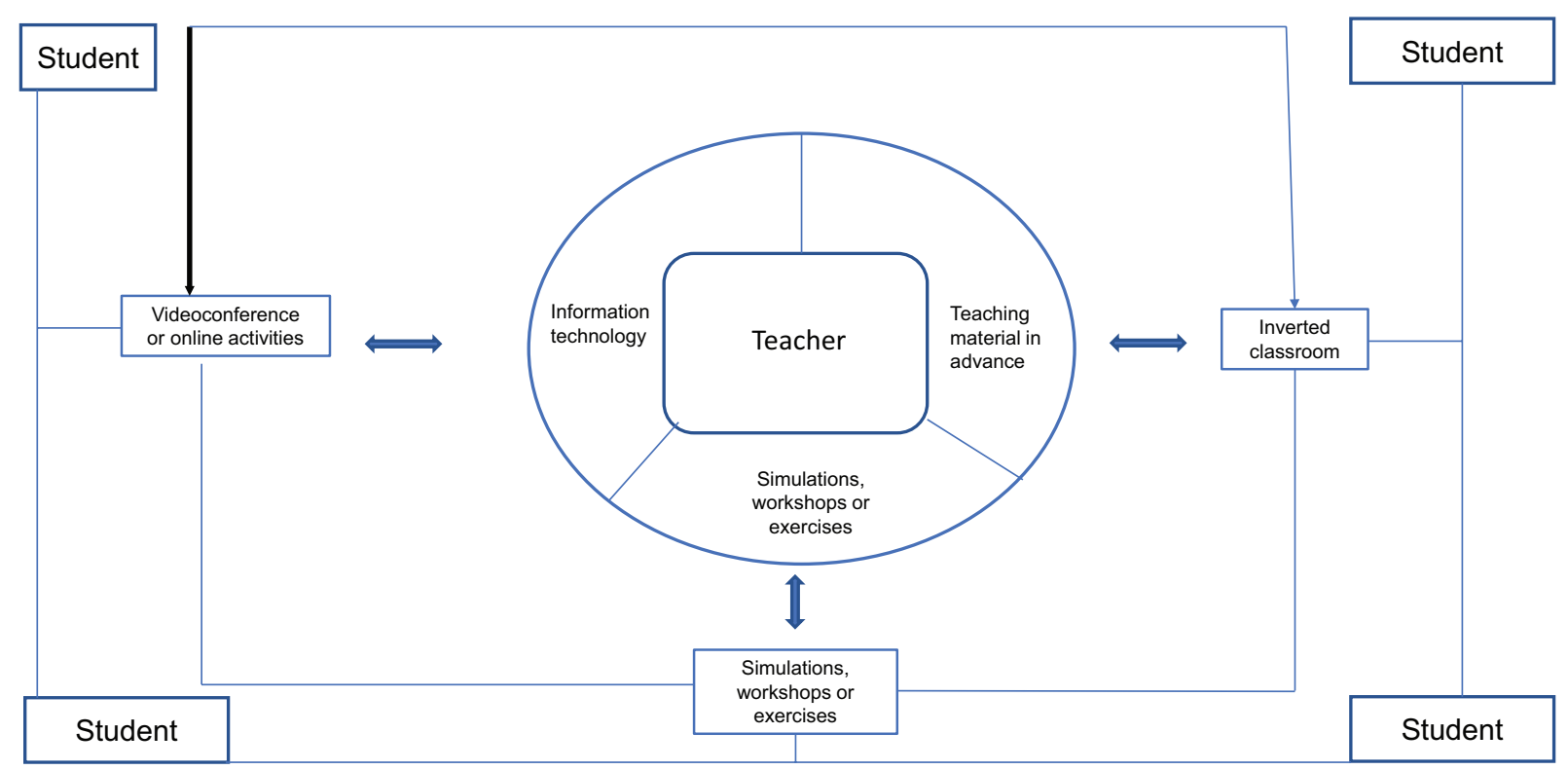

Figure 5. Proposed structure for courses during a pandemic.

Despite the above, the 2009 influenza A (H1N1) pandemic did not represent the creation of a longrange program for health professionals; while the epidemiological surveillance system did improve, response capacity of the institutions, hospitals, and health personnel directly involved in care did not. The ideal scenario would be for each stakeholder to know what they have to do, how and why. ${ }^{9,32,33}$ Neither was there an improvement in the university curricula for increasing knowledge in public health and disaster medicine. Unfortunately, students will assume important decision making on future events without the necessary training; ${ }^{34,35}$ for example: anesthesiologists and critical medicine specialists provide comprehensive medical care in emergency departments, operating rooms and intensive care units, although few receive training in disaster medicine and epidemiological contingencies. ${ }^{36}$

Medical residency represents an opportunity to implement training interventions that promote appropriate 
professional skills and behaviors. ${ }^{16}$ Health education is necessary in order to raise awareness among health workers, ${ }^{37}$ hence proposals have been made for greater investment in their training so that they can help mitigate the risks posed by disease outbreaks. ${ }^{38}$ The task is not always easy, as there are technological, language and time barriers and, above all, no linkage to existing study plans, the contents of which are saturated (Fig. 5). Simulation-based knowledge acquisition can be found at practically all levels of medical training; investment can be high and it requires an economic evaluation to know if a system is capable of including it in its programs. ${ }^{39,40}$

In addition to the above, there are few specialties where courses such as Advanced Life Support in Trauma, Basic Life Support or modules aimed at reviewing public health concepts are required. If, in addition, the lack of workshops and drills in disaster management and health contingencies is added, it is explained why medical students and specialty students cannot be considered a response group for health contingencies. ${ }^{41-43}$

\section{Perspectives and conclusions}

Public health experts have pointed out the need of preparedness to face a pandemic of similar dimensions to that caused by influenza in 1918, with the main problem of not knowing how or when it will occur. ${ }^{12}$ They have assumed that influenza virus $\mathrm{H} 9$ subtypes (mainly H9N2) could be responsible, due to their high rates of zoonotic infection and pandemic potential, which is why efforts have been focused on them. ${ }^{44}$

At 11 years of the influenza $A$ (H1N1) pandemic, the SARS-COV-2 virus emerged, with a high capacity of person-to-person transmission and a calculated lethality ranging from $5 \%$ to $6 \%$, which has forced social isolation, with the consequent impact on economy all over the world. ${ }^{45}$ The health measures learned throughout history, many of them since 1918, are implemented one century later in a world that is poorly prepared for a health crisis such as the one COVID-19 is causing. ${ }^{46}$ In addition, fear and psychological-psychiatric problems are added, as well as health personnel mistrust with regard to authorities, related to the lack of knowledge on the containment and mitigation measures; those who do not know the basic elements will feel threatened, without the proper guidance and direction of a leader. ${ }^{47,48}$ The epidemic externalizes usual or "endemic" personal and institutional deficiencies; fortunately, they can be solved through investment in education, among other things. ${ }^{49}$

Contrary to the general perception that physicians are professionals of rapid response to disasters and pandemics, the conclusions drawn in different scientific journals indicate that the training of medical professionals does not allow them to establish themselves as personnel who can face them, despite the willingness to do it. ${ }^{50}$ Furthermore, in crises there is an imminent risk of academic courses discontinuation, with the consequent poor preparation of students, which forces the review of the teaching process.

Structural modifications of an academic program are difficult owing to all the influencing factors; furthermore, they depend on the organization examining its educational situation, proposing solutions, revolutionizing its system and taking into account the best scenario to achieve its goals. Both health crises and disasters favor the change of educational paradigms, as long as the opportunity is not missed.

\section{Conflict of interests}

The authors declare that there are no conflicts of interest, and neither any financial relationship that may influence on the content of this article.

\section{Funding}

No funding has been received for the development of the manuscript.

\section{Ethical disclosure}

Protection of people and animals The authors declare that no experiments were performed on humans or animals for this research.

Confidentiality of data The authors declare that no patient data appear in this article.

Right to privacy and informed consent The authors declare that no patient data appear in this article.

\section{References}

1. Dodd CN, Romio SA, Black S, Vellozzi C, Andrews N, Zuber P, et al. International collaboration to assess the risk of Guillain Barré Syndrome following Influenza A (H1N1) 2009 monovalent vaccines. Vaccine. 2013;31:4448-4458.

2. Charu V, Chowell G, Palacio-Mejía LS, Echeverría-Zuno S, Borja-Aburto $\mathrm{VH}$, Simonsen $\mathrm{L}$, et al. Mortality burden of the $\mathrm{A} / \mathrm{H} 1 \mathrm{~N} 1$ pandemic in Mexico: A comparison of deaths and years of life lost to seasonal influenza. Clin Infect Dis. 2011;53:985-993.

3. Wong JY, Kelly H, Ip DK, Wu JT, Leung GM, Cowling BJ. Case fatality risk of influenza A (H1N1pdm09): A systematic review. Epidemiology. 2013;24:830-841. 
4. Morse SS. Factors in the emergence of infectious diseases. Emerg Infect Dis. 1995;1:7-15

5. Pandemic influenza preparedness and response. WHO guidance document. Switzerland: World Health Organization; 2009

6. Fineberg HV. Pandemic preparedness and response - Lessons from the H1N1 influenza of 2009. N Engl J Med. 2014;370:1335-1342.

7. Bell DM, Weisfuse IB, Hernández-Ávila M, del Río C, Bustamante X, Rodier G. Pandemic influenza as 21 st century urban public health crisis. Emerg Infect Dis. 2009;15:1963-1969.

8. Seale H, Leask J, Po K, Maclntyre CR. "Will they just pack up and leave?" - Attitudes and intended behavior of hospital health care workers during an-influenza pandemic. BMC Health Serv Res. 2009:9:30.

9. Aiello A, Khayeri MY, Raja S, Peladeau N, Romano D, Leszcz M, et al. Resilience training for hospital workers in anticipation of an influenza pandemic. J Contin Educ Health Prof. 2011;31:15-20.

10. Gates B. Innovation for pandemics. N Engl J Med. 2018;378:2057-2060

11. Alpuche-Aranda CM. Infecciones emergentes, el gran reto de la salud global: Covid-19. Salud Pub Mex. 2020;62:123-124.

12. Gates B. Responding to Covid-19, a once in a century pandemic? New Engl J Med. 2020.

13. Lazcano-Ponce $E$, Alpuche-Aranda C. Alfabetización en salud pública ante la emergencia de la pandemia por Covid-19. Salud Publica Mex. 2020.

14. Lifshitz A. Tendencias de la educación médica. Gac Med Mex. 2000;1:25-33

15. Hutchins SS, Jansen HA, Robertson SE, Evans P, Kim-Farley RJ. Studies of missed opportunities for immunization in developing and industrialized countries. Bull World Health Organ. 1993;71:549-560.

16. Boyce MR, Katz R. Community health workers and pandemic preparedness: Current and prospective roles. Front Public Health. 2019;7:1-5.

17. Emanuel EJ. Reforming American medical education. Milbank Q. 2017:95:692-697

18. Qualls N, Levitt A, Kanade N, Wright-Jegede N, Dopson S, Reed C, et al. Community Mitigation Guidelines to Prevent Pandemic Influenza - United States, 2017. MMWR. 2017:66:1-34.

19. Sambala EZ, Manderson L. Anticipation and response: pandemic influenza in Malawi, 2009. Glob Health Action. 2017;10:1341225.

20. Simonsen L, Chowell G, Andreasen V, et al. A review of the 1918 herald pandemic wave: importance for contemporary pandemic response strategies. Ann Epidemiol. 2018;28:281-288.

21. Rewar S, Mirdha D, Rewar P. Treatment and prevention of pandemic H1N1 influenza. Ann Glob Health. 2015:81:645-653.

22. Sullivan GM. The tragedy of the medical education commons. J Grad Med Educ. 2016;8:1-4.

23. Another step in higher medical education. JAMA. 2016:316:2280

24. Echevarría-Zuno S, Monroy-Ramírez LE, Palacios-Jiménez NM, Loría-Castellanos SJ, Gallardo-Candelas SA. Estrategia educativa en línea durante el brote de influenza A H1N1. Rev Med Inst Mex Seguro Soc. 2010;48:383-392.

25. Khamis N, Aljumaiah R, Alhumaid A, Alraheem H, Alkadi D, Koppel C, et al. Undergraduate medical students' perspectives of skills, uses and preferences of information technology in medical education: a cross-sectional study in a Saudi Medical College. Med Teach. 2018;40:S68-S76.

26. Hays R. Establishing a new medical school: A contemporary approach to personalizing medical education. Med Teach. 2018:40:990-995.

27. Hiromoto $Y$, Parchariyanon S, Ketusing N, et al. Isolation of the pandemic (H1N1) 2009 virus and its reassortant with an H3N2 swine influenza virus from healthy weaning pigs in Thailand in 2011. Virus Res. 2012:169:175-181.

28. Kanehira K, Takemae N, Uchida Y, Hikono H, Saito T. Reassortant swine influenza viruses isolated in Japan contain genes from pandemic A(H1N1) 2009. Microbiol Immunol. 2014:58:327-341.

29. Walsh K. Medical education: return on investment. Ulster Med J. 2015;84:111-112.
30. Sandars JE. Critical theory and the scholarship of medical education. Int J Med Educ. 2016;7:246-247.

31. Seale H, Leask J, Po K, Maclntyre CR "Will they just pack up and leave?" - attitudes and intended behavior of hospital health care workers during an influenza pandemic. BMC Health Serv Res. 2009;13.

32. Sočan M, Erčulj V, Lajovic J. Knowledge and attitudes on pandemic and seasonal influenza vaccination among Slovenian physicians and dentists. Eur J Public Health. 2013;23:92-97.

33. Hines L, Rees E, Pavelchak N. Respiratory protection policies and practices among the health care workforce exposed to influenza in New York State: Evaluating emergency preparedness for the next pandemic. Am J Infect Control. 2014:42:240-245.

34. Fink BN, Rega PP, Sexton ME, Wishner C. START versus SALT Triage: Which is preferred by the 21 st century health care student? Prehosp Disaster Med. 2018:33:381-386.

35. Costantino C, Amodio E, Calamusa, G, Vitale F, Mazzucco W. Could university training and a proactive attitude of coworkers be associated with influenza vaccination compliance? A multicentre survey among Italian medical residents. BMC Med Educ. 2016;16:38.

36. Tuohetamu S, Pang M, Nuer X, Mohemaiti P, Qin Y, Peng Z, Zheng J, $\mathrm{Yu} \mathrm{H}$, Feng L, Feng $\mathrm{L}$. The knowledge, attitudes and practices on influenza among medical college students in Northwest China. Hum Vaccin Immunother. 2017;13:1688-1692.

37. Walsh K, Roma E, Hilton A. Education and support for healthcare professionals to prevent future pandemics: Report of a conference workshop. Ulster Med J. 2018:87:194-196.

38. Hayanga HK, Barnett DJ, Shallow NR, Roberts M, Thompson CB, Bentov I, Demiralp G, Winters BD, Schwengel DA. Anesthesiologists and disaster medicine: A needs assessment for education and training and reported willingness to respond. Anesth Analg. 2017;124:1662-1669.

39. Ling Y, Cheng A, Hecker K, Grant V, Currie GR. Implementing economic evaluation in simulation-based medical education: challenges and opportunities. Med Educ. 2018:52:150-160.

40. Robinson LA, Turner IJ, Sweet MJ. The use of gamification in the teaching of disease epidemics and pandemics. FEMS Microbiol Lett. 2018;365:fny111.

41. Pérez-Gómez HR, Ramos-Zúñiga R. La educación médica y su impacto en la salud pública. Perspectivas y retos. Cir Cir. 2012;80:200-208.

42. Mortelmans LJ, Bouman SJ, Gaakeer MI, Dieltiens G, Anseeuw K, Sabbe MB. Dutch senior medical students and disaster medicine: a national survey. Int J Emerg Med. 2015;8:77.

43. Pfeiffer JK. Is the debate and "pause" on experiments that alter pathogens with pandemic potential influencing future plans of graduate students and postdoctoral fellows? mBio. 2015;1:e02525.

44. Peacock THP, James J, Sealy JE, Iqbal M. A global perspective on H9N2 Avian influenza virus. Viruses. 2019;11:620.

45. Lai CC, Shih TP, Ko WC, Tang HJ, Hsueh PR. Severe acute respiratory syndrome coronavirus 2 (SARS-CoV-2) and coronavirus disease-2019 (COVID-19): The epidemic and the challenges. Int J Antimicrob Agents. 2020;55:105924.

46. Ren SY, Gao RD, Chen YL. Fear can be more harmful than the severe acute respiratory syndrome coronavirus 2 in controlling the corona virus disease 2019 epidemic. World J Clin Cases. 2020;8:652-657.

47. Huang Y, Zhao N. Generalized anxiety disorder, depressive symptoms and sleep quality during COVID-19 outbreak in China: A web-based cross-sectional survey. Psychiatry Res. 2020;288:112954.

48. Shi Y, Wang J, Yang Y, Wang Z, Wang G, Hashimoto K, et al. Knowledge and attitudes of medical staff in Chinese psychiatric hospitals regarding COVID-19. Brain Behav Immun Health. 2020;4:100064.

49. Gates B. The next epidemic- Lessons from Ebola. N Engl J Med. 2015;372:1381-1384.

50. Tomášková $H$, Boháčová $S$, Šlachtová $H$. Attitudes of the medical students from two Czech universities to pandemic Flu A (H1N1) 2009 and to influenza vaccination. Cent Eur J Public Health. 2012;20:215-218. 